\title{
The Role of Schengen in the Development of Peripheral Borderland Regions
}

\author{
Szabolcs Pásztor \\ College of Nyíregyháza, Faculty of Economics and Social Sciences, Institute of Business Administration, Nyíregyháza \\ pasztorsz@nyf.hu
}

Keywords: Schengen borders, cross-border interactions, external peripheries

\section{SUMMARY}

\begin{abstract}
This study aims to uncover the role of the Schengen borders of the European Union in rural and settlement development. Schengen integration applies certain restrictions at the external border-crossings, so the filtering role is to be taken into consideration. In addition to the disappearance of borders in the globalising economic area, the strict Schengen rules further burden the development of cross-border interactions, bringing about less frequent border crossings. Moreover, the economic integration of the affected borderlands would remain sluggish. The author points to the fact that the dynamics of a border interaction system should include a Schengen border degree between the interdependent and integrated borderland levels. Consequently, the Schengen borderlands should be in the focus of further border studies.
\end{abstract}

\section{INTRODUCTION}

With the expansion of globalisation and economic integration tendencies, the formerly deeply separating borders of Western Europe and Central and Eastern Europe are undergoing a dramatic change. In our contemporary world, these borders are disappearing and gaining a new meaning as far as borderland interactions are concerned.

The disappearance of borders gives a new interpretation for the cross-border territories and brings about new advantages and disadvantages in connection with rural and settlement development. In this new context, the question of borders and borderland regions remain an important factor in the economic geography.

This research field has a long development path. Beginning from the the end of the XIX century a large number of geographists for example Batten, Johansson, Guichonnet, Raffestin, Hansen, Martinez, Prescott, Ratti, Ancel, Anderson, Ante, Aschauer, Clement, Courlet, Houtum, Paasi, Perkmann, Ratzel, Scott, Schmitt-Egner have focused on the role of state borders. They have made large-scale research on the development and changes of borders because in the centralized states the border territories became pheripheries in comparison with the central regions. The development of peripheries became a significant problem in the integrating Western Europe because the rural and underdeveloped territories put an insurmountable obstacle in the way of further economic integration and brought several divisions in the common economic area.

The political changes and the further enlargement of the European Union (EU) brought about a new role of the state borders in Central and Eastern Europe as well where previously the question of borders was prohibited to study. The scientific research of borders in this region began just in the late eighties. The results of some Hungarian scientists, e.g. Baranyi, Berényi, Csordás, Dancs, Enyedi, Erdösi, Éger, Fodor, Frisnyák, Golobics, Hajdú, Hardi, Horváth, Illés, Kobolka, Kocsis, Kovács, Lengyel, Majdán, Mészáros, Nárai, Nemes Nagy, Pál, Rechnitzer, Ruttkay, Sallai, Süli-Zakar, Szónokyné should be mentioned. These researchers have focused on the role of borders and borderlands, the feature of external peripheries and cross-border relations.

This study also wants to deal with the above mentioned questions with the aim of futher expanding the determining factors of the development of external, borderland peripheries. Namely, the Schengen borders of the EU still have a significant interaction shaping role further hindering the integration of mostly underdeveloped territories into the global economy. It can be a hypothesis that the current Schengen borders significantly contribute to the development and sluggish integration of external peripheries bringing further divisions in the global economy. Consequently, it is suggestible that the Schengen borderlands should have a special place in the dynamics of border interactions worked out by Martinez and the further scientific examination of this question is indispensable.

\section{MATERIALS AND METHODS}

First, the exact determination of state borders, borderland regions, external peripheries and Schengen is necessary in order to approach the role of Schengen border from the above mentioned different angle. Taken these into consideration, the study determines the features of external Schengen peripheries than points to the role of stricter border-crossing rules.

\section{State borders}

The notion border has several meanings, especially in philosophy, mathematics, geometry, history and geography. This study focuses just on the political state borders with the aim of determining the effect of state borders in connection with rural development and economic welfare. 
One of the historical heritages of Europe is that its territory is divided by small-sized states and their borders. The state borders of today are modern phenomena and they came to the fore in the XVIII and XIX centuries. The borders separating one country from the other became the base of sovereignty of the central power and emblem of unity. Later they morphed into state borders (Hardi, 2009). Friedrich Ratzel, the founder of political geography, distinguished geographic and political borders and one of his laws is about the state borders. In his interpretation, the border is a kind of peripheral organ of the state, an organic complementary part with the main aim of defence and separation (Ratzel, 1892).

In history, until recent times, a border meant a kind of politicaly drawn line or in military terms a stricly shielded territory between two countries. The border is a symbolic emblem expressing separation where the scope of authority of one state begins and the other's terminates. The state exercises its nation state function withing the borders (Rechnitzer, 1999). Süli Zakar oversteps the line character and argues that in political and geographical terms the border is such a zone, lane or line which is capable of separating the territory of states from each other (Süli Zakar, 2003). In Paasi's interpretation, every border let it be the membrane of a living creature or be it a border of a nation, on the one hand is a barrier, on the other the field of communication and exchange (Paasi, 1996). According to Stassoldo, the borders separate and link, joining and the internal territory, coupling the external, barriers and bridges, fields of defence and attack (Strassoldo, 1989). The same separating and linking dichotomy is mentioned by Magris who claims that a border is a bridge towards others and at the same time barrier against them (Magris, 2001, quoting Houtum et al., 2003).

In Hungary the Law on Border Defence and Border Guards gives authentic and legal defintion for the borders. The state border of the Republic of Hungary: "The sequence of those internationally agreed visionary and vertical lines which separate the territory of Hungary in air, on the ground and under the surface from the territory of other countries." (Sallai, 2004)

\section{The Functional Division of State Borders}

The approach of the definition of borders from different angles leads to the functional divison. The most well-known and widely accepted dichotomy contains the separating and linking words (Nárai- Rechnitzer, 1999). However, the state borders can have separating-linking, insecuring-defending, excluding-surrounding or detaching, filtering and/or oper features as well (Novotny, 2003).

These functions can be found in every case and taking their effect into consideration, the borders can be separating, filtering and open. A closed, barrier type border has strong coercive feature, strengthening the peripheral tendencies and characters in the given area. The filter type border does not hamper the free movement but filters and controls a number of interactions mainly towards to external side of the border. The open border gives free pass, movement, and resident and economic transactions, posing only less significant barriers in the way of the adverse movements. Guichonnet and Raffestin (1974) gave - to a certain extent - a different approach for the functional division of borders. In their views the three functions of borders: legal, fiscal, controlling and in certain cases military and ideological. Further four basical functions can be found in different theoretical writings: separating element (barrier), filtering zone with gates (filter), edge and collision zone (frontier) and linking element (contact zone) (Nemes Nagy, 1998). Tóth elaborates a graphic modell for the possible forms of spatial connections arguing that the borders hinder the economic integration and economic and social development. In a border-free area the connections are concentric but the former Central and Eastern European borders were rigid bringing only asymmetric development (Tóth-Golobics, 1996).

\section{Borderlands and External Peripheries}

Borders have such a special role as a spacial element that they have a richer meaning for the scientists of regional and border studies. Consequently, the description of borderlands is a more complicated task.

There are different points of view when we try to determine certain frontier territories. According to the common belief, the borderlands expression means a $15-25 \mathrm{~km}$ wide area at both sides of the border (Baranyi, 2008). Under the name of borderlands those basic statistical regional units (settlement, small region, region) are meant which directly associates with state borders. However, this approach has a huge drawback depending on the research level. The edge of a cross-border zone - according to a large number of researchers - can be drawn where the presence of a state border influences the social and economic trends better than the distance of the nearest centre. Hansen argues that the border zone is a territory where the state border has a significant shaping role in the socio-economic tendencies (Hansen, 1983).

The fate of the borderland settlements and the life quality of the population is basically influenced by the feature of the border. The life quality of the borderland population improves when the cooperation possibilities between regions, settlements and countries widen. Where the transmissivity of borders increases, there the linking character of the borderlands strengthens. In those regions, the border's separating and dividing features remain stronger, further preserving periphery status.

The borderlands in many cases still lie - in terms of geography - in the periphery which means a hugely detrimental situation (Mackinder, 1996). The mentioned peripheries have unfavourable natural geographic capabilities, bad infrastructure, underdeveloped socio-economic structural system and lie far from the 
administrative and cultural centres. Immanuel Wallerstein points to this special feature in 1983, when he talks about the center and periphery dichotomy (Wallerstein, 1983).

It must be seen that thanks to the already mentioned tendencies it is not taken for granted that borderlands represent peripheral territories. The border status could mean advantages and disadvantages as well. Western European examples confirm that the borderland status does not necessarily mean peripheral status yet it can be advantegous. Some Western European Euroregional practices - Regio Basiliensis, Piedmont Region, MeuseRhine Euroregion - testify to this. In the last decades, in Central and Eastern Europe, the disadvantages prevailed. A kind of shift was experienced some years ago, when the internal borders of the EU came into existence, while there are some borderlines where the number of border-crossings is far from the potential.

As a consequence, it must be mentioned that border, periphery and peripheral status are not the same in terms of definitions. The border status is the special version of peripheries; a kind of qualified case. There are more peripheral areas in a country than borderlands (Éger, 1998). These are the internal peripheries (for example Middle-Tisza Region in Hungary) which represent closed, badly connected areas. The external peripheries can be found next to state borders and these borders significantly contribute to the evolution of underdeveloped regions by restricting the concentric feature of economic tendencies.

\section{THE ROLE OF SCHENGEN IN CROSS-BORDER INTERACTIONS}

The Schengen Agreement, which played a decisive role in the establishment of the free flow of people, was signed on 14 June 1985, in Schengen. Later, in 1990, the EU member states signed the Convention implementing the Schengen Agreement and it came into force in 1995. In the meanwhile, the Single European Act was created in 1987, extending the action of the Community into new areas. In the history of Schengen integration, a remarkable moment was the eastern enlargement of the EU and the creation of the European Constitution. On 1 May 2004, customs checks ceased at the internal border crossings, while at the external border crossings, stricter conditions were put into place. Hungary, for example, became a member of the Schengen Zone on 21 December 2007 and, as a result, the internal and external borders are also legally determined in the legal system. The Schengen Borders Code defines the internal border, which is the common border of member states, including rivers, lakes seas and airports, harbours capable of launching and receiving international planes and ships. The outer borders are not internal borders. They include borders at lakes, rivers, seas, airports, harbours.

By now, with the available border-crossing data and empirical studies, it can be seen that in the Carpathian Basin, the Schengen borders show separating, filtering and linking functions. The separating feature prevails mainly alongside the external borders which is well-presented by the stricter rules of entrance conditions and border defence. The filtering feature is present in every case, but it is more dominant alongside the external borders. The linking feature is prevalent in case of the internal borders, where the entry is free and unrestricted day after day.

The external Schengen borders significantly determine the relations between the areas, settlement and the population of neighbouring borderlands. The cooperation-based common borderlands mean a new quality in the relation of bordering areas. The steps of the interconnection are preseted in the dynamics of border interactions modell (Martinez, 1994) which tracks the frequency and capacity of interactions between frontier regions. The modell distinguishes four categories from the aspect of character and depth of cooperation so the birth of a new border region is described by four degrees. One of the drawbacks of the modell is the case when certain administrative or other actions (for example Schengen rules) hamper the further development of interactions and pose a kind of artifical wall in the fusion of different or previously coherent territories. The study presents the four degrees by including the fifth which lies between the third and fourth (Figure 1).

Figure 1. Dynamics of Border Interactions

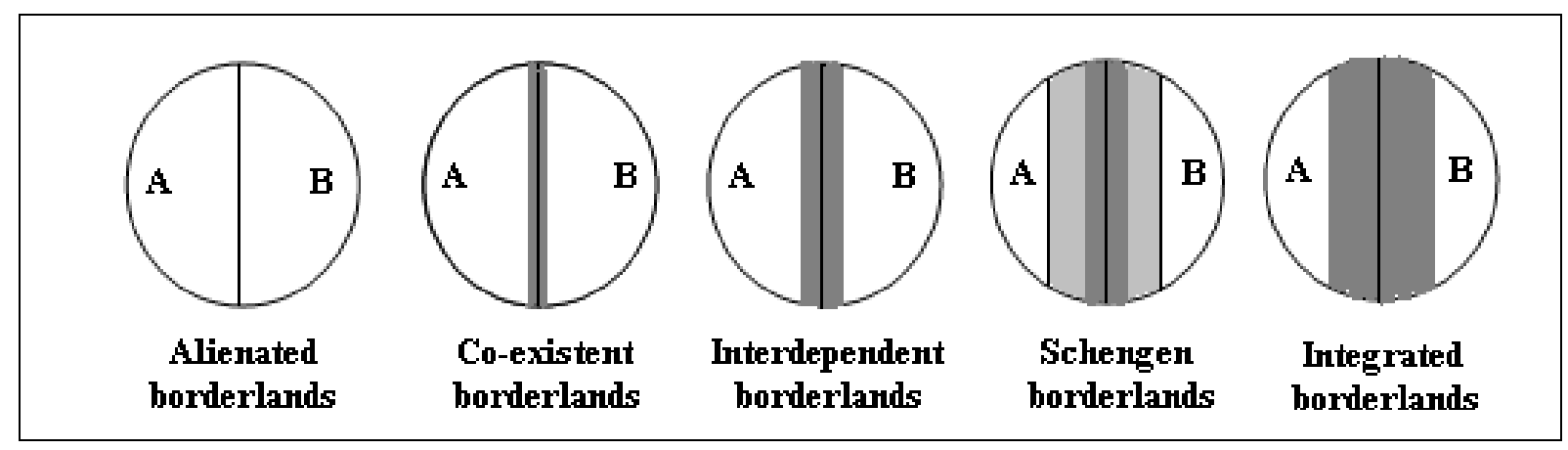

Source: Own compilation based on the dynamics of border interaction modell by Martinez 
The alienated borderlands represent tensions between the parties. The border is closed and the interactions are completely or almost fully missing. The citizens of both states look upon the other party as an alien. The coexistent borderlands, as a type, present a situation where the relations are stable but not friendship-based. In this case, the border is partly open and there are possibilities for bilateral international relations. A closed cooperation is peculiar to the interstate relations, the residental relations are rare. In the case of interdependent borderlands, the relations are more developed than in previous cases. The evolution of amicable and cooperative relations and the widening of interactions are helped by economic and social complementary circumstances.

As for Schengen borderlands, the cross-border relations are said to be developed, but the strict border-crossing rules significantly burden border-crossing activity. The external Schengen borders serve as filtering gates at the borderlines and stall the evolution of deeper cross-border interactions. In addition, they do not help the economic integration of peripheral areas by putting up barriers. The integrated borderlands suppose strong and permanent stability. A prerequisite for the fulfilment is the unrestricted flow of people and goods. The functional fusion of the economies can be achieved. The development process takes up much time, but in the end, it can re-establish the unity of a given area and create a common territory.

\section{CONCLUSIONS AND DISCUSSIONS}

Thanks to its economic integration tendencies, the borders of the European Union are disappearing, giving way to cross-border trade and development. The evolution of border territories is almost complete in Western Europe, where only internal borders exist. However, the external borders (Schengen borders) further slow territorial integration, because the stricter border-crossing rules significantly lower the activity of interaction. In this study, the author pointed to the fact that the Schengen borderlands should have a special place in the dynamics of border interactions, because they represent a kind of transition between interdependent and integrated borderlands. These external borders further restrict the development of mainly peripheral regions, so in the forseeable future, we cannot expect much - just a kind of sluggish growth - from the integration of these territories. The Schengen status requires further scientific research, because a better understanding is indispensible for the elaboration of development programes for external, rural peripheral regions.

\section{REFERENCES}

Baranyi B. (2008): A határmentiség dimenziói Magyarországon. Dialóg-Campus Kiadó, Budapest, 17-47.

Éger Gy. (1998): Az eurorégió mint az európai integráció sajátos térbeli vetülete. Külpolitika. 4. 76-87.

Guichonnet P.-Raffestin C. (1974): Géographie des frontiers. Presses Universitaires de France, Paris, 74.

Hansen N. (1983): International Cooperation in Border Regions: an Overview and Research Agenda. International Regional Science Review. 8. $456-477$.

Hardi T. (2009): Határok és városok a Kárpát-medencében. MTA RKK. Győr-Pécs, 11-37.

Houtum H. van et al. (2003): (Re)bordering the European Union: Scrutinizing the Border Regime of an Enlarging European Union. „EXLINEA”-Research Framework. Nijmegen Centre for Border Research Department of Human Geography, University of Nijmegen, The Netherlands. (Manuniscript)

Mackinder H. J. (1996): Democratic Ideals and Reality: Study in the Politics of Reconstruction. National Defence University Press, Washington, DC.

Martinez O. J. (1994): The Dynamics of Border Interaction: New Approaches to Border Analysis, Global Boundaries (World Boundaries Series 1.) London, New York, 1-15.

Nárai M.-Rechnitzer J. (szerk.) (1999): Elválaszt és összeköt - a határ. Társadalmi- gazdasági változások az osztrák-magyar határ menti térségekben. Pécs-Györ, MTA Regionális Kutatások Központja

Nemes Nagy J. (1998): Tér a társadalomkutatásban. Hilscher Rezső Szociálpolitikai Egyesület, Budapest, 259.

Novotny G. (2003): Határon átnyúló regionális hálózatok Európában. PhD értekezés. Pécs, 2003, (Manuscript)

Paasi A. (1996): Territories. Bondaries and Consciousness (The Changing Geographies of the Finnish-Russian Border). P.T. Taylor - J. O'Loughlin (serieseds.). John Wiley, Chichester, 24.

Ratzel F. (1892): Allgemeine Eigenschaften die geographiscen Grenzen und die politische Grenze

Rechnitzer J. (1999): Határ menti együttmüködések Európában és Magyarországon. In: Elválaszt és összeköt - a határ. MTA RKK, PécsGyör. 10.

Sallai J. (2004): Az államhatárok. Változó Világ, 58. Press Publica Kiadó, 11.

Strassoldo R. (1989): Border Studies. The State of the Art in Europe, Transborder Cooperation Policy Promotion at the Local Level. A. J. Asiwaju (ed.): West-African Experience focusing on Nigeria and Adjacent Countries, Regional Development Dialoge, $2.156-72$.

Süli Zakar I. (2003): A határ menti területek (külső perifériák) fejlesztésének kérdései. In: A terület-és településfejlesztés alapjai. (Szerk.: Süli-Zakar I.) Dialóg Campus Kiadó, Budapest-Pécs, 223.

Tóth J.-Golobics P. (1996): Régiók és interregionális kapcsolatok a Kárpát-medencében. In: Frisnyák S. (Szerk.): A Kárpát-medence történeti földrajza. MTA Szabolcs-Szatmár-Bereg Megyei Tudományos Testülete, Bessenyei György Tanárképző Főiskola, Földrajz Tanszék, Nyíregyháza, 107-119.

Wallerstein I. (1983): A modern világgazdasági rendszer kialakulása. A tőkés mezőgazdaság és az európai világgazdaság eredete a XVI. században, Gondolat, Budapest. 